AWEJ for Translation \& Literary Studies, Volume 4, Number3. August 2020

DOI: http://dx.doi.org/10.24093/awejtls/vol4no3.3

Pp. $34-45$

\title{
Feminism's Last Frontier in the Quest for Social Theory: American Stand-up in the Age of Political Correctness
}

\author{
Youcef Bennaa \\ Department of English Faculty of Letters and Languages \\ Dialogue of Religions and Civilizations in the Mediterranean Basin Laboratory \\ Abou Bekr Belkaid University, Tlemcen, Algeria \\ Faiza Meberbeche Senouci \\ Department of English Faculty of Letters and Languages \\ Dialogue of Religions and Civilizations in the Mediterranean Basin Laboratory \\ Abou Bekr Belkaid University, Tlemcen, Algeria
}

\begin{abstract}
The socio-cultural status of stand-up comedians allowed them to comment with impunity on sensitive social issues, giving them the ability to normalize and abnormalize certain societal behaviors and beliefs. This Foucaultian social tool attracted the use of many historically disenfranchised groups on the merits of sexuality and race. Feminists noted a gender discrepancy in pay and appearance in the hierarchy of this industry and attributed it to systemic flaws, not just with the industry but with humor's theoretical and conceptual structures. The aim of this research work is to assess the impact of their ideological quest for a new theory of humor on the integrity of American stand-up comedy. The application of Peterson's "Political Correctness Game" framework suggests that there are possible ulterior motives behind calls to change the foundational structure of American stand-up. The problem that this paper attempts to address is whether calls for inclusivity in the framework of intersectionality theory in humor can be characterized as a legitimate call to limit, what the feminist labeled, as acts of hubris and humiliation against victimized minorities? Or are these calls permeating into dangerous social and even legal territories, where comedians' rhetoric is regulated and their artistic freedom is infringed upon? This paper contended that feminist calls for a new theory of humor derived from intersectionality lens would only create "echo chambers" of already like-minded individuals, rather than exerting social change through the subaltern social power that can be generated from stand-up humor.
\end{abstract}

Keywords: feminism, humor, intersectionality, political correctness, social theory, stand-up

Cite as: Bennaa, Y., \& Senouci, F. M. (2020). Feminism's Last Frontier in the Quest for Social Theory: American Stand-up in the Age of Political Correctness. Arab World English Journal for Translation \& Literary Studies 4 (3) 34-45.

DOI: http://dx.doi.org/10.24093/awejtls/vol4no3.3 
AWEJ for Translation \& Literary Studies Volume, 4 Number 3 August 2020

Feminism's Last Frontier in the Quest for Social Theory

Bennaa \& Senouci

\section{Introduction}

"What devices are more explosive in the social sphere more discomforting to our conventional modes of thought, more invasive of our quasi-private store of associations, than the well-placed joke, the display of wit, or the well-honed use of irony?" (Willett \& Willett, 2019, p.218)

The character of the modern-day stand-up comedian evolved through several antecedents including, the archetypal figure of the mythological trickster (Tafoya, 2009), the European Court jester (Donian, 2018), and the Shakespearean character of the "wise fool" (Donian, 2018). These historical antecedents occupied a marginal position in society due to a mental or physical disability, (Otto, 2001) hardly garnering any sociopolitical status. However, as this sociological phenomenon, which is Stand-up, evolved in the contemporary American context, it became a multimillion-dollar industry (Love, 2017) and it granted its practitioners, especially those who excel at it an ambiguously vague position society. This position allowed them to comment with impunity on sensitive social issues, giving them the ability to normalize and abnormalize certain societal behaviors and beliefs. This Foucaultian social tool attracted the use of many historically disenfranchised groups on the merits of sexuality and race (Donian, 2018) to normalize and even empower their status in American society. One particular group, however, -feminists- noted a gender discrepancy, in pay and appearance (Love, 2017; Shapiro, 2019) in the hierarchy of this industry and attributed it to systemic flaws, not just with the industry but with its theoretical and conceptual structures. (Willett et al. 2012) In this paper the author examines the evolution of this particular art form and explore its appeal and its ability to legitimize, what Donian argued as "otherwise irredeemably obscene, ugly or unworthy" (Donian, 2018, p.11). Moreover, drawing from the works of (Willett et al. 2012) and (Willet \& Willet, 2019) the author delves into the feminists' grievances with the four dominant theories of laughter namely superiority, incongruity, play and relief. The author also explores their diagnosis and consequent calls for a new theory of intersectionality in humor, particularly in American stand-up. Some scholars in the field of sociology (Russell, 2002) and (Brodie, 2014) carefully question the idealist approach of feminism in terms of trying to avoid self-deprecation, others (Hitchens, 2017) in less subtle ways. The researcher will draw upon these critiques and apply the "PC Game" ideological model (Peterson, 2016) to verify possible ulterior motives behind calls to drastically change the foundational structure of American stand up. The problem that this paper attempts to address is whether calls for inclusivity in the framework of intersectionality theory in humor can be characterized as a legitimate call to limit, what the feminist labeled, acts of hubris and humiliation against victimized minorities? Or are these calls permeating into dangerous social and even legal territories, where comedians' rhetoric is regulated and their artistic freedom is infringed upon? The aim of this research work is to assess the impact of an ideological quest for a new theory of humor on American stand-up comedy. The study of comedy in academia is gaining prominence, especially in the fields of social sciences and humanities, and for good reasons, as argued by Peter Berger when he stated that: "Studying the comic dimension of social reality is not meant to denigrate the serious study of society but simply to suggest that such study itself will profit greatly from those insights that one can obtain only while laughing" (Berger \& Luckmann, 2011, p.165).

Arab World English Journal for Translation \& Literary Studies 
AWEJ for Translation \& Literary Studies Volume, 4 Number 3 August 2020

Feminism's Last Frontier in the Quest for Social Theory

Bennaa \& Senouci

Therefore, this article attempts to bring discussions about this comedic genre into the broad conversation of the socio-cultural aspects of American Studies.

\section{Literature Review: Stand-up Comedy as a Subversive Art Form}

The rigidity and linearity of history's ability to register events and document facts are indeed important in shaping and maintaining humanity's connection to its past experiences. This has a tremendous role in forming our memories as individuals and societies, which is not only essential for our development and growth but rather vital. However, the fact-based approach of history cannot fill the equally vital repository of human emotions. Documenting past human emotional experiences belongs outside the sphere of history and social sciences. This highly subjective task belongs to a different realm altogether; art. Art does more than just preserve how "it felt" in different chronological and geographical settings. It can influence or even create feelings and sentiments, which are the cornerstone of any social experience (Phillips, 2000). Historians being the storytellers that they are have generated a respectable status in society driven by the fact that they have a reputation of being a reliable academic source of information about our past. But that is hardly a heart capturing or a sought-after social status on a larger social scale, no offense to historians or academics. This can be blamed, at least in part, on the values of mercantilism during the Renaissance (Phillips, 2000). These Renaissance rich merchants developed a taste for art and made it profitable and "fancy" to become artists. This tradition of artistic appreciation prospered in Europe, and ultimately reached the US. The break from philistine traditions of medieval Europe helped to launch a booming artistic industry that had created, to put it mildly, more socially admired individuals. This admiration was due to their ability to harness the creativity that enabled individuals and groups to experience "enhanced" feelings at deeper personal and collective levels. These enhanced feelings ranged from awe, melancholy to uncontrollable laughter. The generation of this last particular manifestation of joy has been historically reserved to court jesters and clowns, hardly an inspiring position to seek. However, with the monetization of theater and comedy films, making people laugh started to be financially and socially appealing. When there are money and status at play the competition ensues. And when competition takes place a hierarchy gets established (Zoglin, 2009). There is one particular variation of comedy this research paper is interested in, which is a raw, bare and most importantly solo performance of comedic expression. Of course this is referring to the stand-up comedy. Standup comedy features a single comic standing in front of an audience, hence the concept of stand-up comedy, with the purpose of making that group of people laugh. In the United States the concept of stand-up comedy came to prominence during the mid-twentieth century but in the form of "a uniquely oratorical form of entertainment that has been both captivating and provocative" (Meier et al. 2017, p. xxii). However, stand-up comedy and its archetype humor are not just provocative and captivating, but they can also function as "rhetoric with practical and theoretical consequences" (Sorensen, 2019, p.186). Rhetoric consequences cannot get more practical and provocative than what happened to one of the earliest figures of American stand-up comedy. In 1961 Leonard Alfred Schneider better known by his stage name Lenny Bruce, got arrested for what can only be described as a ridiculous charge in modern-day America (Meier et al. 2017). The charge was being obscene with his artistic expression, particularly using profanity in front of live audiences. (Meier et al. 2017) Even though he was released, he continued with this practice until

Arab World English Journal for Translation \& Literary Studies 
he became a trailblazer for a group of comedians that defined an era and paved the way for a different, provocative and most importantly socially subversive genre of comedy. It is perhaps a coincidence that this genre of provocative comedy coincided with the era of counterculture antiestablishmentarianism that took place in 1960 America, or it could be a byproduct of those sentiments of rebellion against conservatism, either way it made those who do it, and precisely excel at it, famous, rich, and more relevantly listened to by large segments of society. So the platform that these stand-up comedians and those who followed them were on top of was not just to deliver jokes and punch lines, but also to deliver subliminal messages that can be subversive to specific cultural and societal norms. The ability to subvert social norms through ridicule has always been the go-to means if reason falters to change the status quo. This was articulated by Susan Douglas, a cultural critic, when she stated that:

If reason as a persuasive tool is at best only indirectly effective, and a weak tool on its own, might not the sting of ridicule or the contagion of joyous laughter prove to be more effective weapons for social change. (Willett et al. 2012, p.218)

Foucault (1995) also addressed this particular issue and highlighted the importance of ridiculing certain social norms for the purpose of pushing them to their ultimate demise. He stated that: “(...) Given that social norms shape cognitive habits the unraveling and disrupting of conventional norms through ridicule might free our thinking as well" (Foucault, 1995, p.30). Freedom, whether at the abstract or the concrete levels, requires a breaking of certain structures that usually come in the form of a hierarchy.

These social hierarchies, especially those that involve the dichotomy of the oppressor/ oppressed rather than those that have been built around some level of fair competition, do not usually have rotations between individuals and groups at the top and individuals and groups at the bottom. (Magee \& Galinsky, 2008) That is why they are unsustainable and often get destroyed rather than modified and gentrified (Magee \& Galinsky 2008) One of the modern tools of bringing down hierarchies is humor. According to cultural critic Douglas: "Humor has a subversive effect on the dominant culture... [And that] it does not reinforce or inverse hierarchies; it levels of them" (Douglas, 1994, p.95). This will lead us to delve into how stand-up comedy and the humor this art form generates can change social norms and level certain hierarchies.

\section{The Importance of the Frontier: Stand-up's Mechanisms of Instigating Social Activism and Awareness}

"Humor both reveals and produces intersubjectivity, a cultural mortar or strain of recognition and alliance among even the most tenuously related persons...The "unity" of this intersubjectivity of laughing together occurs through suspending reified positions of identity" (Henderson, 2007, p.135). One mechanism of how stand-up comedy can be a useful tool for social influence is that it can carry an audience composed of different ethnicities, backgrounds, ideologies and belief systems to different metaphorical places and make them laugh there. Laughter can be both used for normalizing certain "new" social norms or ridiculing "old" ones. The normalization strategy in stand-up as argued by Foucault (1995) works to regulate and refine our modes of discourse and

Arab World English Journal for Translation \& Literary Studies 
what we know about our bodies and minds and most importantly hold as normal. Succumbing to normality is not just to be accepted by society but also to not receive punitive consequences for certain beliefs or behaviors. Because according to McWhorter: "The target of the disciplinary apparatus in modern-day society is abnormality (...) Nonconformity [is] not mere eccentricity; very often it was symptomatic of disease" (McWhorter, 2009, p.34). This is not unique to stand-up, but also hold true for a myriad of art forms. But unlike the relatively intimate setting of other form of entertainment like TV and Cinema, stand-up relies on creating "shock" resorting to "obscene material" to remove the audience from their social and psychological comfort zones to new territories and make them laugh there. A relatively recent example of this social tactic being utilized by a comic to "normalize" a lewd behavior was in a stand-up performance by a comedian called Louis CK. In his act he attempted or instead floated the idea in his setup that the reason why child molesters end up killing their victims is basically because of the irredeemable and irremovable social stigma surrounding those who get caught molesting a child (CK, 2015). He then went on to establish a cringing premise where he stated that: "But it's true, if we minded child molesting less, less kids would die" (CK, 2015). To the horror of the audience, the number three Best comedian of all time according to Rolling Stone Magazine (Love, 2017) doubled down: "It's true, it's true" but stopped short of actually providing legal and social guidelines of how to make that happen. In his "punchline" that can only be described as a retraction or a pause, he admitted that he does not know what to do with this information, "cracking" many laughs from the stunned and confused audience. This highly controversial experience in comedy was compatible with a philosophical view of laughter put forward by John Morreall, professor of religious studies and the founder of the international society for human studies (Morreall, 2016). Morreall's conceptualization of laughter is that it:

Is the result a psychological 'shift,' a sudden change in one's mental or affective statewhich is pleasant in character...This conceptual shift occurs when the expectations engendered by our general picture of the world, including our picture of the social world, fail to be met (Donian, 2018, p.290)

When and if this process is executed successfully in the context of stand-up comedy, rendering a social norm normal or abnormal is much easier to achieve. Most if not all social groups in America have utilized this tactic in stand-up for several goals, mainly to normalize their culture and promote their assimilation (Donian, 2018). This is not surprising given its efficacy. However, one particular group feels they are not adequately represented at "the big boys' table" of the world of American stand-up. This group is the feminist movement, which in its idealistic quest for gender equality, correctly observed a significant sex-based disparity when it came to comics at the top of American stand-up hierarchy. An example of this observation is that under the category of "Comedy" and sub-genre "stand-up comedy," there are 205 results listed on the popular streaming Network Netflix, thirty-four or about $16.6 \%$ are specials performed by women comedians (Ausländer, 1993). The intricacies as to why exactly this is the state of American stand-up are the subject of vigorous debate that will be discussed in the following section.

Arab World English Journal for Translation \& Literary Studies 
AWEJ for Translation \& Literary Studies Volume, 4 Number 3 August 2020

Feminism's Last Frontier in the Quest for Social Theory

Bennaa \& Senouci

\section{A Feminist Diagnosis of American Stand-up: Towards a New Theory of Humor}

The "beef" that some feminists like Cynthia Willett, Julie Willett and Yael Sherman have with the industry of stand-up comedy as a whole is not just the inadequate number of feminist comedians at the top echelon of its hierarchy, but instead with the hierarchy itself. That "beef" is also extended to the theories that had defined the concept of humor in the last centuries. Prior to delving into the feminist perception of what humor and stand-up in particular ought to be, definitions of what humor and the laughter that it generates need to be revisited. Chronologically one of the earliest conceptualization of humor was the superiority Theory. This theory originated from Biblical and platonic readings, which stated that humor comes from the pleasure of mocking others, which usually involves superior and inferior sides (Morreall, 2016). Then during the seventeenth and eighteenth centuries two theories emerged that moved the definition of humor away from the Superiority Theory into a more sophisticated Realm. These theories are relief and incongruity (Morreall, 2016). Relief as the name suggests, argues that the laughter provides a catharsis of emotions and tension. (Willett \& Willett, 2019) This Theory originated from an essay by Lord Shaftesbury in 1709 entitled "An essay of the freedom of wit and humor" (Morreall, 2016). The third theory is incongruity. Its proponents include Kant and Kierkegaard and its account of laughter is that it is "a violation of mental patterns or anything that offers surprise" (Willett \& Willett, 2019, p.5). The fourth, final and most recent theory is called play. In 1936 Max Eastman came up with the idea that there are commonalities between primates' play, particularly chimpanzees and humor (Morreall, 2016). These theories according to feminists fail to "register the social power of subaltern laughter" and hence show a clear "central bias in standard philosophical conception of what humor is" (Willett \& Willett, 2019, p.4). Therefore, what they argue for is a new philosophical conception of laughter, a new theory or in Cynthia and Julie Willett's words: "a new lens [that] is focused on a path towards social equality," with one golden rule "One always punches up and never down" (Willett et al. 2012, p.9). Practical applications of this theory are summarized by three key examples. The first was related to the Charlie Hebdo cartoons depicting Prophet Muhammad (peace be upon him) and the ensuing events in 2015. The dissection of this particular example, the related arguments and recommendations of this research paper will be left to the final part after laying down the feminist and "anti-feminist" views regarding the use of offensive and lewd material in comedy. The feminist position on the obscene "humor" of the French cartoonist, granted a different genre than stand up, was unorthodox from the group widely perceived to be at the liberal left of the ideological spectrum. A commonly held position was articulated by the Willetts when they stated: "While the 2015 Paris Massacre was a tragic overreaction to the cartoons, the derogatory portrayal of a revered figure for a devalued radicalized minority may register as an act of hubris and humiliation" (Willett et al. 2012, p.8). This same perspective is extended to the other two examples relating to race and gender. They continued their articulation of this novel theory of humor by stating that: "Black slurs are not appropriate in the context of white supremacy, nor are misogynistic rape jokes in patriarchal cultures" (Willett et al. 2012, p.5). And the rationale behind all of these "prohibitions" or at least recommended restrictions is that: "An insult might feel like sticks and stones, thus might result in significant harm" (Willett et al. 2012, p.8). This seemingly idealistic lens of an ethical reformation of humor comes from the feminist obsession with theory, but not any theory, rather a theory with a capital T. According to Hailey: “(...) Feminists romance with a theory with a capital T of

Arab World English Journal for Translation \& Literary Studies 
domination should give way to a politics and Hedonics, in fact to an erotic politics that is, as she puts it, "fun" (Hailey, 2006, p.13). These inner calls to "lighten up" from within the feminist camp, acknowledge the problem in this particular lens. The specific target of this criticism is one brand of feminism called "Governance Feminism," or in the words of Hailey "Schoolmarm-ish Feminism, who take themselves as experts on political correctness and who play innocent to their own will to power" (Hailey, 2006, p. 7). However, there are calls outside the feminist ideological spectrum, which claim that the new feminist theory for humor has malicious ulterior motives. The most vocal of these calls is a psychologist named Jordan Peterson, who has been admittedly labeled by some feminists as "the custodian of the patriarchy" (Bowels, 2018).

\section{A More Sinister Plot at Play: Applying Peterson's "PC Game" Ideological Model}

The context in which this model has been created was in response to what Jordan Peterson called political correctness aimed at targeting the most critical tenets of Western Civilization; the competence-based hierarchical structures of its institutions (Peterson, 2016). Peterson, a University of Toronto clinical psychologist, is considered by economist Tyler Cowen, one of the most influential economists in the past decade, ("Economics' most influential," 2011) to be "the most influential public intellectual in the Western world right now" (Brooks, 2018). Peterson (2016) suggested that the motives behind this "political correctness game" were a "Marxist plot" driven by resentment. This plot was called the long march through the institutions. It entailed "working against the established institutions while working within them, but not simply by 'boring from within,' rather by 'doing the job"' (Peterson, 2016). Every game has certain rules that its players need to abide by to compete and the "PC game" is no exception. Peterson (2016) identifies a set of different rules or rather different stages to play this particular game. In one of his many online lectures he stated that the rules are:

$>$ Identifying an area of human activity, and note a distribution of success.

$>$ Identify winners and losers.

$>$ Define those doing worse as victims, and those doing better as perpetrators or oppressors.

$>$ Claim allegiance with the supposed victims.

$>$ Revel in your moral superiority.

$>$ Target your resentment towards your newly discovered enemies.

$>$ Repeat. Forever. Everywhere.

Obviously, the depiction of feminist calls for further integration of feminist comics and feminist comedy in the world of top-level American stand-up, as a Marxist plot to undermine the artistic integrity of this institution might seem far-fetched and borderline conspiracy theory, still for the sake of academic fairness it had to be considered, due to the validity of many of its projections. The human activity in the context of this research work is American stand-up. The distribution of success in this multimillion-dollar industry is overwhelmingly in favor of male comics. The Forbes list of the highest-paid American stand-up comedians of 2019 only one female comedian managed to enter in the top ten, which is Amy Schumer (Shapiro, 2019). Another important statistics that feminists like to highlight is the fact that Rolling Stone magazine published a list of 50 comedians 
AWEJ for Translation \& Literary Studies Volume, 4 Number 3 August 2020

Feminism's Last Frontier in the Quest for Social Theory

Bennaa \& Senouci

that it considered the best ever to perform stand-up in the history of the United States. Among this list only eleven female comics featured and only one woman was in the top thirty, Joanne Rivers (Love, 2017). The rational observer would hold judgment until all variables are accounted for to explain this discrepancy. However, according to the model laid down earlier, men, who are the oppressors, keep women, the victims, in the lower levels of this particular hierarchy. Not just any category of men, but precisely heterosexual men. This projection is one example of how the intersectionality theory is applied to the hierarchy of stand-up comedy. This qualitative analytical framework, that this theory offers helps in identifying intertwined modes of power which influencee, according to its proponents, those who are socially marginalized (Disch \& Hawkesworth, 2016). The empathy or in Jordan Peterson's words, allegiance to the oppressed or the victims would automatically generate disdain and hostility towards those who are considered the oppressors. The next stage in this game is to have an enemy or a set of enemies that are handy to "vent resentment on." Enter the infamous Vanity Fair article by social "provocateur" Christopher Hitchens. Hitchens gained prominence in mainstream media outlets and in TV shows with his usual controversial statements including supporting the Iraq War and his anti-religion writings (See Arguably: Essays 2011). However, what triggered feminist disdain, understandably, was an article entitled Why Women Aren't Funny. Where he unleashed a scathing satirical attack against women's ability to be funny, citing a study by Stanford University School of Medicine, and some behavioral evolutionary arguments to support his case (Hitchens, 2017). To add insult to injury Hitchens borrowed aspects of the intersectionality playbook and claimed that the only women who are funny or can be funny are: "hefty, dykey, or Jewish" (Hitchens, 2017) ticking all the outrage boxes in feminist thought. The reaction to this article included labeling the author with the typical jargon of chauvinist pig (Marcotte, 2014) woman-hater, and misogynist (Beyerstein, 2011). Another top ten comedian of all time echoed Hitchens' remarks but in a more subtle way. CK (2016) indicated that even though he knows “... many many funny women and I don't think it's a female trait, but no men has or will ever do that" in the context of appreciating and creating comedy. He also received scathing push back. This theme of feminists' lack of humor had emerged in most of the material of high-profile comedians like Carlin (Brodie, 2014), Chappelle (2018) and Gervais (Brodie, 2014) to name a few, but I digress. Evaluating the material of comedians as regular political discourse would provide those who do that with an easy feeling of moral superiority. However, that would miss what stand-up comedy is supposed to be, which is one of the points that are going be discussed in the following, findings section.

\section{Findings and Discussion: A Scenario for the Future of Stand-up}

"I say a lot of mean things. I'm not saying it to be mean I'm saying it because it's funny. And everything is funny until it's happening to you" (Chappelle, 2018). Peterson's model might "fit like a glove" to analyze these supposed ulterior or "real" motives behind feminists" push for a new theory in stand-up comedy. And even though some of the rhetoric coming out of the discussions of the previously mentioned feminist theorists in particular about the need to break comedy to rebuild it, might confirm his suspicions. But confining the desire of feminists who wish to penetrate the male-dominated field of stand-up comedy in just feelings of resentment might put Peterson in the same trap that he accuses "left-wing ideologues" of falling into, which is the oversimplification of reality. However, there is also the need for this particular type of feminism, which was labeled

Arab World English Journal for Translation \& Literary Studies 
AWEJ for Translation \& Literary Studies Volume, 4 Number 3 August 2020

Feminism's Last Frontier in the Quest for Social Theory

Bennaa \& Senouci

in this research as "governance feminism" to perceive comedy in its true essence, as described by early philosophers like Aristotle and Plato, and even as practiced by early practitioners of this art form like Carlin and Joanne Rivers, as the self-deprecatory, shocking, and vulgar art form that it is. The spin, however, is that this vulgarity would make stand-up, as Carlin surmised, "the art of the people" (Brodie, 2014, p.3). Contemplating that the structure of a joke, a setup and a punch line, to be patriarchal (Votruba, 2018) or appealing exclusively to "scattered niche markets comprised of like communities such as LGBTQIA popular culture enthusiasts" (Krefting, 2014, p.33) would only create "bubbles" and echo chambers that fail to instigate the sought-after social influence that might exist in the subaltern part of stand-up comedy. The Charlie Hebdo controversy provoked a myriad of different reactions, invoking concepts such as censorship and freedom of artistic expression, and many concepts in between. Feminists perceived this issue with their intersectionality lens of the standpoint theory, which depicted the scenery as a "punch down" from a perceived oppressor, a French and Western cartoonist, to the "downtrodden and victimized" Muslim world. The reactions that ensued pushed the Charlie Hebdo magazine to the forefront of mainstream media and society and led to the unprecedented economic gains for the fringe magazine (Weaver, 2014). Needless to say the tactic of violence and censorship was counterproductive to all those who were antagonized by the cartoons. These are two different genres of comedy, but the same old saying goes, "if you don't like the jokes, stay out of the comedy club." If one is to reverse this tactic, and instead of the feminists' suggestion of shielding certain groups from punches from superiorly privileged groups, that all groups regardless of social privilege are projected to "punches from all directions," this beautiful art form, that is stand-up, can manage to survive, prosper and perhaps be more inclusive.

\section{Conclusion}

This paper has established the importance of the subversive nature of humor in American stand-up comedy providing clear examples of how it gained prominence starting in the 1970s and 1980s as a tool for instigating social activism and awareness. This paper also contended that feminist calls for a new theory of humor derived from intersectionality lens would only create "echo chambers" of already like-minded individuals, instead than exerting social change through the subaltern social power that can be generated from stand-up humor. It also recognized that regardless of whether Peterson's assumptions about the ulterior motives of such calls for reform in stand up as being driven solely by resentment are valid or not, the most important observation in his theory is that trying to regulate the scope of comedic freedom, which represents the catalyst for creativity and competitiveness in this particular hierarchy would constitute a pathway to undermine its artistic integrity. This paper concluded that trying to "protect" specific groups from being subjected to mockery and ridicule is not only untenable, but rather undesirable and counterproductive, and would further solidify and legitimize the oppressed/oppressor dichotomy. Instead, this research work suggested that all groups regardless of perceived social or political privilege are subjected to "punches from all directions," or ruthless humor that takes people irrespective of their perceived identity to metaphorical places, where they have fear, anxiety, and discomfort and make them laugh there, even at their expenses. What are the actual causes that explain the insufficient number of women at the top of American stand-up hierarchy? What are the tangible measures that can be taken to alleviate the manifestation of inhibited social behavior

Arab World English Journal for Translation \& Literary Studies 
AWEJ for Translation \& Literary Studies Volume, 4 Number 3 August 2020

Feminism's Last Frontier in the Quest for Social Theory

Bennaa \& Senouci

keeping women from moving forward in the world of stand-up comedy? How can we ensure a sustainable future where we ensure that the sensitive balance of high-quality comedy and an inclusive environment for women and minorities is maintained? These questions and more can all be raised to build a foundation based on enough consensus to move forward towards a future where this beautiful art form of the people can prosper.

\section{About the authors:}

Youcef Bennaa: holds a Magister degree in American Studies. He is an assistant teacher at the University of M'sila, Algeria. Currently, he is preparing his PhD thesis at the University of Abou Bekr Belkaid, Tlemcen, Algeria. His major research interests are American Studies, Gender studies, American history. https://orcid.org/0000-0002-1326-6436

Prof. Faiza Meberbeche Senouci: is a senior lecturer at the University of Tlemcen, department of English. Currently, she is in charge of different courses. Her major interests are Pan-African History, American civilization, Culture, Identity and Religion. https://orcid.org/0000-0001-51539987

\section{References}

Ausländer, P. (1993). 'Brought to you by Fem-Rage': Stand-up Comedy and the Politics of Gender. Ann Arbor: University of Michigan Press.

Barecca, G. (ed.). (1988). Last Laughs: Perspectives on Women and Comedy. New York: Gordon and Breach Science Publishers.

Beyerstein, L. (2011, December 20). Four antidotes to Hitchens hagiography. In These Times. Retrieved from: http://inthesetimes.com/dulynoted/entry/12454/

Berger, P. L., \& Luckmann, T. (2011). The Social Construction of Reality: A Treatise in the Sociology of Knowledge. New York NY: Open Road Media.

Bordo, S. (1999). The Male Body: A New Look at Men in Public and in Private. New York: Farrar Straus and Giroux.

Bowels, N. (2018, May 18). Jordan Peterson, Custodian of the Patriarchy. The New York Times. Retrieved from https://www.nytimes.com/2018/05/18/style/jordan-peterson-12-rules-forlife.html

Brodie, I. (2014). A vulgar art: A New Approach to Stand-up Comedy. Mississippi: University Press of Mississippi.

Brooks, D. (2018, January 25). The Jordan Peterson Moment. The New York Times. Retrieved from https://www.nytimes.com/2018/01/25/opinion/jordan-peterson-moment.html

Bunch, C. (1987). Not by Degrees: Feminist Theory and Education. New York: St. Martin's Press.

Chappelle, D. [PBS News Hour]. (2018, July 7). Dave Chappelle on Comedy in the \#MeToo moment [Video]. Youtube. https://www.youtube.com/watch?v=yTv1wJ_VUgY

Cho, M. [januaryfairy]. (2002, June 7). I'm the one that I want. [Video]. Youtube. http://www.youtube.com/watch?v=iY9G52IKsyc

CK, L. [ScotSpeed]. (2015, June 6). Louis CK and the Child Molester Paradox [Video]. Youtube. https://www.youtube.com/watch?v=grm3YUKmmhs

Arab World English Journal for Translation \& Literary Studies 
AWEJ for Translation \& Literary Studies Volume, 4 Number 3 August 2020

Feminism's Last Frontier in the Quest for Social Theory

Bennaa \& Senouci

CK, L. [Neighborhood Watch]. (2016, December 23). Louis CK - Can Women be Funny? [Video]. Youtube. https://www.youtube.com/watch?v=cRNP7Hh1DMg

Cooper, B. (2016). Intersectionality. In Disch, L., Hawkesworth, M. (Eds.), The Oxford Handbook of Feminist Theory (pp. 385-406). New York, NY: Oxford University Press.

Dean, G, \& Allen, S. (2008). Step by Step to Stand-up Comedy. Portsmouth, NH : Heinemann.

Douglas, M. (1999). Implicit Meanings: Essays in Anthropology. London and New York: Routledge.

Douglas, S. J. (1995). Where the Girls are: Growing up Female with the Mass Media. New York: Random House.

Donian, J. (2018). Taking Comedy Seriously: Stand-up's Dissident Potential in Mass Culture. Maryland: Rowman \& Littlefield.

Finney, G. (1994). Look Who's Laughing: Gender and Comedy. Amsterdam: Gordon and Breach.

Foucault, M. (1995). Discipline and Punish: The Birth of the Prison (A. Sheridan, trans.). New York: Vintage Books.

Hailey, J. (2006). Split Decisions: How and Why to Take a Break from Feminism. Princeton: Princeton University Press.

Henderson, L. (2007). Chick flicks: Contemporary Women at the Movies. New York: Routledge.

Heath, G. L. (1976). Off the Pigs! The History and Literature of the Black Panther Party. Lanham, MD: Roman and Littlefield.

Hitchens, C. (2017). Why Women Aren't Funny. Vanity Fair. www.vanityfair.com/culture/2007/01/hitchens200701.

Huffer, L. (2009). Mad for Foucault. New York: Columbia University Press.

Krefting, R. (2014). All Joking Aside American Humor and its Discontents. Maryland: The Johns Hopkins University Press.

Love, M. (2017). 50 Best Stand-up Comics of All Time. Retrieved from https://www.rollingstone.com/culture/culture-lists/50-best-stand-up-comics-of-all-time$126359 /$

Magee, J., \& Galinsky A. D. (2008). Social Hierarchy: The Self-Reinforcing Nature of Power and Status. The Academy of Management Annals, 2(1), 351 - 398. DOI: 10.1080/19416520802211628

Marcotte, A. (2014). Atheism's Shocking Woman Problem: What's behind the Misogyny of Richard Dawkins and Sam Harris? Retrieved from https://www.salon.com/2014/10/03/new_atheisms_troubling_misogyny

McWhorter, L. (2009). Racism and Sexual Oppression in Anglo-America: A Genealogy. Bloomington: Indiana University Press.

Meier, M. R., \& Schmitt. C. R. (eds.). (2017). Standing up, Speaking out: Stand-up Comedy and the Rhetoric of Social Change. New York: Routledge.

Mintz, L. (1985). Standup Comedy as Social and Cultural Mediation. American Quarterly 37 (1), 71-80.

Morreall, J. (2016). Philosophy of Humor. The Stanford Encyclopedia of Philosophy. $<$ https://plato.stanford.edu/archives/win2016/entries/humor/>.

Mottura, B. (2018). Media and politics: Discourses, Cultures, and Practices. Newcastle upon Tyne: Cambridge Scholars Publishing.

Arab World English Journal for Translation \& Literary Studies 
AWEJ for Translation \& Literary Studies Volume, 4 Number 3 August 2020

Feminism's Last Frontier in the Quest for Social Theory

Bennaa \& Senouci

Ortmanns, C. (2017). Irony's Potential as Subversive Strategy: A Case Study of Anti-Racist Standup Comedy. The Maastricht Journal of Liberal Arts, 8, 49-63. DOI:10.26481/mjla.2016.v8.521.

Otto, B. (2001). Fools Are Everywhere: The Court Jester Around the World. Chicago: Chicago University Press.

Peterson, J. [Jordan B Peterson]. (2016/10/05) Part 3: The PC Game (and some countertactics) [Video]. Youtube. https://www.youtube.com/watch?v=W2u62u4entc

Phillips, M. (2000). Society and Sentiment: Genres of historical writing in Britain, 1740-1820. New Jersey: Princeton University Press.

R, A. (2011). Economics' Most Influential People. The Economist. Retrieved from https://www.economist.com/blogs/freeexchange/2011/02/economics\&fsr

Russell, D. (2002). Self-deprecatory humor and the Female Comic: Self-destruction or comedic construction?" Third Space: A Journal of Feminist Theory and Culture, 2(1). https://journals.sfu.ca/thirdspace/index.php

Shapiro, A. (2019). The Highest-earning Stand-up Comedians of 2019. Retrieved from https://www.forbes.com/sites/arielshapiro/2019/08/16/the-highest-earning-stand-upcomedians-of-2019/\#37ad95d942fa

Sorensen, J. (2008) Humor as a Serious Strategy of Nonviolent Resistance to Oppression. Peace and Change: A Journal of Peace Research, 33(2), 167-190. https://doi.org/10.1111/j.1468-0130.2008.00488.x.

Tafoya, E. (2009). The Legacy of the Wisecrack: Stand-up Comedy as the Great American Literary Form. Boca Raton: Brown Walker Press.

Votruba, K. (2018). Redefining Feminist Rhetoric in Stand-up Comedy: Offering Cultural Critique Through Subversion and Silence, (Unpublished Master's thesis). Iowa, US: Iowa State University Dissertations.

Weaver, M. (2014, January 14). Charlie Hebdo Print Run raised to $5 \mathrm{~m}$ as Copies in France sell out. The Guardian. Retrieved from https://www.theguardian.com/media/2015/jan/14/

Willett, C., Willett, J., \& Sherman, Y. D. (2012). The seriously erotic politics of feminist laughter. Social Research: An International Quarterly, 79 (1), 217-246.

Willett, C., \& Willett, J. (2019). Uproarious: How feminists and other subversive comics speak truth. London: University of Minnesota Press.

Young, M. (1990). Justice and the politics of difference. Princeton: Princeton University Press.

Zoglin, R. (2009). Comedy at the Edge: How Stand-up in the 1970s Changed America. London, UK: Bloomsbury Publishing.

Arab World English Journal for Translation \& Literary Studies 